\title{
The Impact of Children's Long-Term Participation in STEM Clubs on Their Attitudes towards STEM Subjects
}

\author{
Cem Kagar ${ }^{1}$ \\ Teslime Kagar ${ }^{1}$
}

1Payas STEM Centre

DOI: $\underline{10.21585 / \mathrm{ijcses} . v 0 \mathrm{i} 0.51}$

\begin{abstract}
In this report we investigated the impact of after school STEM clubs on children's attitudes to STEM related subjects. 236 children aged 8-12 took part in this study. For the purpose of this study, a quantitative research method was adopted where a survey prior to the STEM activities and at the end of 30 weeks of after school club have been used to make sense of children's perspectives on STEM related subjects. The study also explored whether the age and gender of the children would influence their attitudes towards these subjects.
\end{abstract}

Key words: STEM, Engineering, Cross curricular, Computer Science, Primary education

\section{Introduction}

STEM stands for science, technology, engineering and mathematics. The STEM term was introduced by Judith A. Ramaley, the former director of the U.S. National Science Foundation's Education and Human Resources Division in 2001. There is no agreed definition of STEM. Kelley and Knowles (2016) describe STEM as a teaching approach and learning activities with a purpose of connecting science, mathematics, technology and engineering concepts and applications to enhance students learning. Moore and colleagues (2014) focusing on integrated STEM education defines STEM as "an effort to combine some or all of the four disciplines of science, technology, engineering, and mathematics into one class, unit, or lesson that is based on connections between the subjects and real-world problems" (p. 38). According to Allsop (2016) the aim of STEM education is "to blend scientific inquiry and technological design processes through project based learning that focus on developing students' critical thinking, problem solving, logical reasoning, technical, communication, collaboration, self-directing and creativity skills" (p. 120 ) This is also supported by Watson and colleagues, who explained STEM as 'a teaching approach that involves teaching science, technology, engineering and mathematics concepts in an integrated way from early years to higher education' (2013).

We define STEM as a teaching approach that aims to integrate learning in four main disciplines; science, technology, engineering and mathematics through project based activities. This is very important as Huber and colleagues (2005) noted, making connections between different curriculum, disciplines, knowledge and practice can provide learners with a deeper understanding of concepts. Furthermore, STEM learning provides children a platform to investigate a concept or an idea in many different contexts and then connect their learning across disciplines. STEM education helps learners to understand how a tool or a mechanism Works and increases their technological skills (Bybee, 2010). Especially at K-12 level, STEM education enables learners to develop knowledge and skills that are crucial for life and economic development (National Research Council, 2011). The definitions above show that STEM involves integration of disciplines for preparing students to solve real life problems.

\subsection{Why STEM?}

In order to answer this question we need to approach it from different aspects:

1. Economic and technological aspects: STEM education received much interest from industries that were having issues with skill shortages. A recent study completed by the EU Committee on Employment and Social Affairs (2015) reported that "A sufficient labour supply equipped with STEM skills is essential to implement 
the European Agenda for Growth and Jobs". The report also noted that by 2025, there will be 7 million jobs that will require STEM skills (2015, p.8). Furthermore, this report discussed the importance of schools for transforming learners' attitude towards science through STEM activities.

2. Real life aspect: Preparing people for life is not the aim of education; in short, life is a constant education. STEM focuses on real-life problems, which allows children to face crucial problems, and then think about formulating solutions for these.

3. The link between education and industry: One of the aims of education is to prepare people for job prospects. According to the Intel Report (2015); Science, technology, engineering, and math (STEM) disciplines play an increasingly important role in employability.

4. Developing transferrable skills: STEM education enables children to develop 6C skills (critical thinking, collaboration, communication, creativity, citizenship and character education) that are vital for designing solutions to real-life problems.

\section{Methodology}

For the purpose of this study a quantitative research method has been used for making sense of children's attitudes towards STEM related subjects. 236 children aged between 8 and 12 took part in a 30 week long STEM club in 2008 at the Payas STEM Centre. 135 students were male and 105 of them were girls. The sessions included a mixture of mathematics, science, robotics and coding activities. The children completed a pre and post survey to describe their experience of taking part in the STEM club which helped us to gain an insight into their learning process and attitudes towards STEM subjects.

\section{Findings and Discussions}

In the analysis of the data; descriptive statistics; frequency, percentage, mean, standard deviation values are presented. An Independent paired t-test was used to examine whether the mean measurements of the pre-test score changes of the study groups were different. The paired chi-square test was performed to examine whether the study group pre and post-test ratios were different. Correlation analysis was performed to determine the relationship between age, pre-test and post-test. P values less than 0.05 were considered statistically significant $(\alpha=0.05)$. The analyses were done using the SPSS 22.0 package program.

Table 1. Student characteristics

\begin{tabular}{ccc}
\hline Age & $\mathbf{N}$ & \% \\
\hline 8 & 22 & 9,3 \\
9 & 59 & 25,0 \\
10 & 69 & 29,2 \\
11 & 52 & 22,0 \\
12 & 34 & 14,4 \\
\hline Gender & $\mathbf{N}$ & $\mathbf{\%}$ \\
\hline Male & 131 & 55,5 \\
Female & 105 & 44,5 \\
\hline
\end{tabular}

It was determined that $9 \%$ of the students participated in the study were 8 years old, $25 \%$ were 9 years old, $29 \%$ were 10 years, $22 \%$ were 11 years and $14 \%$ were 12 years old. $56 \%$ of the students were male and $44 \%$ were female.

Table 2. Evaluation of Pre-Test and Final Score by Gender

\begin{tabular}{lcccccc}
\hline \multirow{2}{*}{ Statements } & & \multicolumn{2}{c}{ Pre-club } & \multicolumn{2}{c}{ After Club } & \multirow{2}{*}{ P } \\
\cline { 2 - 6 } & & $\mathrm{n}$ & $\%$ & $\mathrm{n}$ & $\%$ & \\
\hline I have information about & Yes & 126 & $53,4 \%$ & 217 & $91,9 \%$ & \multirow{2}{*}{$\mathbf{0 , 0 1 *}$} \\
Stem & No & 110 & $46,6 \%$ & 19 & $8,1 \%$ & \\
\hline The use of Stem activities & Yes & 231 & $97,9 \%$ & 234 & $99,2 \%$ & \multirow{2}{*}{0,63} \\
in the lesson is fun & No & 5 & $2,1 \%$ & 2 &, $8 \%$ & \\
\hline I'm not interested in Stem & Yes & 11 & $4,7 \%$ & 0 & $0,0 \%$ & \multirow{2}{*}{0,13} \\
activities & No & 225 & $95,3 \%$ & 236 & $100,0 \%$ & \\
\hline
\end{tabular}




\begin{tabular}{|c|c|c|c|c|c|c|}
\hline $\begin{array}{l}\text { Designing courses } \\
\text { improves my creativity }\end{array}$ & $\begin{array}{l}\text { Yes } \\
\text { No }\end{array}$ & $\begin{array}{c}228 \\
8\end{array}$ & $\begin{array}{l}96,6 \% \\
3,4 \%\end{array}$ & $\begin{array}{c}235 \\
1\end{array}$ & $\begin{array}{c}99,6 \% \\
, 4 \%\end{array}$ & 0,11 \\
\hline $\begin{array}{l}\text { Stem activities create a } \\
\text { desire to study }\end{array}$ & $\begin{array}{l}\text { Yes } \\
\text { No }\end{array}$ & $\begin{array}{c}209 \\
27\end{array}$ & $\begin{array}{l}88,6 \% \\
11,4 \%\end{array}$ & $\begin{array}{c}209 \\
27\end{array}$ & $\begin{array}{l}88,6 \% \\
11,4 \%\end{array}$ & 0,99 \\
\hline $\begin{array}{l}\text { Stem activities improve } \\
\text { performance }\end{array}$ & $\begin{array}{l}\text { Yes } \\
\text { No }\end{array}$ & $\begin{array}{c}227 \\
9\end{array}$ & $\begin{array}{c}96,2 \% \\
3,8 \% \\
\end{array}$ & $\begin{array}{c}232 \\
4\end{array}$ & $\begin{array}{c}98,3 \% \\
1,7 \% \\
\end{array}$ & 0,90 \\
\hline $\begin{array}{l}\text { I'm interested in using } \\
\text { technology in Stem events }\end{array}$ & $\begin{array}{l}\text { Yes } \\
\text { No }\end{array}$ & $\begin{array}{c}230 \\
6\end{array}$ & $\begin{array}{c}97,5 \% \\
2,5 \% \\
\end{array}$ & $\begin{array}{c}223 \\
13 \\
\end{array}$ & $\begin{array}{c}94,5 \% \\
5,5 \% \\
\end{array}$ & 0,52 \\
\hline I love mathematics & $\begin{array}{l}\text { Yes } \\
\text { No }\end{array}$ & $\begin{array}{c}218 \\
18 \\
\end{array}$ & $\begin{array}{c}92,4 \% \\
7,6 \% \\
\end{array}$ & $\begin{array}{c}230 \\
6\end{array}$ & $\begin{array}{l}97,5 \% \\
2,5 \% \\
\end{array}$ & 0,24 \\
\hline $\begin{array}{l}\text { I did mathematical } \\
\text { modelling before }\end{array}$ & $\begin{array}{l}\text { Yes } \\
\text { No }\end{array}$ & $\begin{array}{l}102 \\
134 \\
\end{array}$ & $\begin{array}{l}43,2 \% \\
56,8 \% \\
\end{array}$ & $\begin{array}{c}204 \\
32 \\
\end{array}$ & $\begin{array}{l}86,4 \% \\
13,6 \% \\
\end{array}$ & $0,01 *$ \\
\hline I like the science course & $\begin{array}{l}\text { Yes } \\
\text { No }\end{array}$ & $\begin{array}{c}227 \\
9\end{array}$ & $\begin{array}{c}96,2 \% \\
3,8 \%\end{array}$ & $\begin{array}{c}230 \\
6\end{array}$ & $\begin{array}{l}97,5 \% \\
2,5 \%\end{array}$ & 0,65 \\
\hline I love group work & $\begin{array}{l}\text { Yes } \\
\text { No }\end{array}$ & $\begin{array}{c}227 \\
9\end{array}$ & $\begin{array}{c}96,2 \% \\
3,8 \% \\
\end{array}$ & $\begin{array}{c}228 \\
8\end{array}$ & $\begin{array}{c}96,6 \% \\
3,4 \% \\
\end{array}$ & 0,92 \\
\hline $\begin{array}{l}\text { I've heard the term Arduino } \\
\text { before }\end{array}$ & $\begin{array}{l}\text { Yes } \\
\text { No }\end{array}$ & $\begin{array}{c}58 \\
178\end{array}$ & $\begin{array}{l}24,6 \% \\
75,4 \%\end{array}$ & $\begin{array}{c}56 \\
180\end{array}$ & $\begin{array}{l}23,7 \% \\
76,3 \%\end{array}$ & 0,95 \\
\hline $\begin{array}{l}\text { I've heard the term Scratch } \\
\text { before }\end{array}$ & $\begin{array}{l}\text { Yes } \\
\text { No }\end{array}$ & $\begin{array}{c}93 \\
143\end{array}$ & $\begin{array}{l}39,4 \% \\
60,6 \%\end{array}$ & $\begin{array}{c}86 \\
150\end{array}$ & $\begin{array}{l}36,4 \% \\
63,6 \%\end{array}$ & 0,42 \\
\hline $\begin{array}{l}\text { I've heard the term microbit } \\
\text { before }\end{array}$ & $\begin{array}{l}\text { Yes } \\
\text { No }\end{array}$ & $\begin{array}{c}64 \\
172 \\
\end{array}$ & $\begin{array}{l}27,1 \% \\
72,9 \% \\
\end{array}$ & $\begin{array}{c}86 \\
150 \\
\end{array}$ & $\begin{array}{l}36,4 \% \\
63,6 \% \\
\end{array}$ & $\mathbf{0 , 0 3 *}$ \\
\hline I've heard code.org before & $\begin{array}{l}\text { Yes } \\
\text { No }\end{array}$ & $\begin{array}{c}34 \\
202\end{array}$ & $\begin{array}{l}14,4 \% \\
85,6 \%\end{array}$ & $\begin{array}{c}203 \\
33\end{array}$ & $\begin{array}{l}86,0 \% \\
14,0 \%\end{array}$ & $0,01 *$ \\
\hline
\end{tabular}

* significant difference, $\mathrm{p}$ values were analysed by chi-square test.

The students' responses of the item "I have knowledge about stem" are different from the pre-test and post-test responses and the level of thinking that the students have knowledge about Stem in the post-test responses is higher than the pre-test $(p=0.01, p<0.05)$. The students' responses of the item "I did mathematical modelling before" was different from the pre-test and post-test responses, and the post-test responses of the students were found to have higher levels of mathematical modeling than the pre-test $(\mathrm{p}=0.01, \mathrm{p}<0,05)$.

It was determined that the distributions of the responses given to the pre-test and post-test differed from the students in terms of the "Microbit term was previously heard" statement, and the students' hearing rates were higher in the post-test responses than in the pre-test $(p=0.03, p<0.05)$. The students' responses of the item "I have heard code.org before" are different from the pre-test and post-test responses, the difference in the post-test response of the students' pre-test rate was found to be higher than the levels $(p=0,01, p<0.05)$.

Table 3. Pre and after club survey analysis in relation to gender

\begin{tabular}{|c|c|c|c|c|c|c|c|c|c|}
\hline \multirow{3}{*}{ Statements } & & \multicolumn{4}{|c|}{ Pre-test } & \multicolumn{4}{|c|}{ Post-test } \\
\hline & & \multicolumn{2}{|c|}{ Male } & \multicolumn{2}{|c|}{ Female } & \multicolumn{2}{|c|}{ Male } & \multicolumn{2}{|c|}{ Female } \\
\hline & & $\mathrm{n}$ & $\%$ & $\mathrm{n}$ & $\%$ & $\mathrm{n}$ & $\%$ & $\mathrm{n}$ & $\%$ \\
\hline \multirow{2}{*}{$\begin{array}{l}\text { I have information about } \\
\text { Stem }\end{array}$} & Yes & 65 & $49,6 \%$ & 61 & $58,1 \%$ & 120 & $91,6 \%$ & 97 & $92,4 \%$ \\
\hline & No & 66 & $50,4 \%$ & 44 & $41,9 \%$ & 11 & $8,4 \%$ & 8 & $7,6 \%$ \\
\hline \multirow{2}{*}{$\begin{array}{l}\text { The use of Stem activities } \\
\text { in the lesson is fun }\end{array}$} & Yes & 127 & $96,9 \%$ & 104 & $99,0 \%$ & 131 & $100,0 \%$ & 103 & $98,1 \%$ \\
\hline & No & 4 & $3,1 \%$ & 1 & $1,0 \%$ & 0 & $0,0 \%$ & 2 & $1,9 \%$ \\
\hline \multirow{2}{*}{$\begin{array}{l}\text { I'm not interested in Stem } \\
\text { activities }\end{array}$} & Yes & 6 & $4,6 \%$ & 5 & $4,8 \%$ & 0 & $0,0 \%$ & 0 & $0,0 \%$ \\
\hline & No & 125 & $95,4 \%$ & 100 & $95,2 \%$ & 131 & $100,0 \%$ & 105 & $100,0 \%$ \\
\hline \multirow{2}{*}{$\begin{array}{l}\text { Designing courses } \\
\text { improves my creativity }\end{array}$} & Yes & 129 & $98,5 \%$ & 99 & $94,3 \%$ & 131 & $100,0 \%$ & 104 & $99,0 \%$ \\
\hline & No & 2 & $1,5 \%$ & 6 & $5,7 \%$ & 0 & $0,0 \%$ & 1 & $1,0 \%$ \\
\hline \multirow{2}{*}{$\begin{array}{l}\text { Stem activities create a } \\
\text { desire to study }\end{array}$} & Yes & 118 & $90,1 \%$ & 91 & $86,7 \%$ & 112 & $85,5 \%$ & 97 & $92,4 \%$ \\
\hline & No & 13 & $9,9 \%$ & 14 & $13,3 \%$ & 19 & $14,5 \%$ & 8 & $7,6 \%$ \\
\hline \multirow{2}{*}{$\begin{array}{l}\text { Stem activities improve } \\
\text { performance }\end{array}$} & Yes & 125 & $95,4 \%$ & 102 & $97,1 \%$ & 130 & $99,2 \%$ & 102 & $97,1 \%$ \\
\hline & No & 6 & $4,6 \%$ & 3 & $2,9 \%$ & 1 & $0,8 \%$ & 3 & $2,9 \%$ \\
\hline
\end{tabular}




\begin{tabular}{lccccccccc}
\hline I'm interested in using & Yes & 127 & $96,9 \%$ & 103 & $98,1 \%$ & 126 & $96,2 \%$ & 97 & $92,4 \%$ \\
technology in Stem events & No & 4 & $3,1 \%$ & 2 & $1,9 \%$ & 5 & $3,8 \%$ & 8 & $7,6 \%$ \\
\hline I love mathematics & Yes & 121 & $92,4 \%$ & 97 & $92,4 \%$ & 127 & $96,9 \%$ & 103 & $98,1 \%$ \\
& No & 10 & $7,6 \%$ & 8 & $7,6 \%$ & 4 & $3,1 \%$ & 2 & $1,9 \%$ \\
\hline I did mathematical & Yes & 56 & $42,7 \%$ & 46 & $43,8 \%$ & 110 & $84,0 \%$ & 94 & $89,5 \%$ \\
modelling before & No & 75 & $57,3 \%$ & 59 & $56,2 \%$ & 21 & $16,0 \%$ & 11 & $10,5 \%$ \\
\hline I like the science course & Yes & 125 & $95,4 \%$ & 102 & $97,1 \%$ & 130 & $99,2 \%$ & 100 & $95,2 \%$ \\
& No & 6 & $4,6 \%$ & 3 & $2,9 \%$ & 1 & $0,8 \%$ & 5 & $4,8 \%$ \\
\hline I love group work & Yes & 124 & $94,7 \%$ & 103 & $98,1 \%$ & 126 & $96,2 \%$ & 102 & $97,1 \%$ \\
& No & 7 & $5,3 \%$ & 2 & $1,9 \%$ & 5 & $3,8 \%$ & 3 & $2,9 \%$ \\
\hline I've heard the term & Yes & 27 & $20,6 \%$ & 31 & $29,5 \%$ & 31 & $23,7 \%$ & 25 & $23,8 \%$ \\
Arduino before & No & 104 & $79,4 \%$ & 74 & $70,5 \%$ & 100 & $76,3 \%$ & 80 & $76,2 \%$ \\
& & & & & & & & & \\
\hline I've heard the term Scratch & & & & & & & & & \\
before & Yes & 51 & $38,9 \%$ & 42 & $40,0 \%$ & 51 & $38,9 \%$ & 35 & $33,3 \%$ \\
& No & 80 & $61,1 \%$ & 63 & $60,0 \%$ & 80 & $61,1 \%$ & 70 & $66,7 \%$ \\
\hline I've heard the term & Yes & 38 & $29,0 \%$ & 26 & $24,8 \%$ & 49 & $37,4 \%$ & 37 & $35,2 \%$ \\
microbit before & No & 93 & $71,0 \%$ & 79 & $75,2 \%$ & 82 & $62,6 \%$ & 68 & $64,8 \%$ \\
\hline I have information about & Yes & 20 & $15,3 \%$ & 14 & $13,3 \%$ & 112 & $85,5 \%$ & 91 & $86,7 \%$ \\
Stem & No & 111 & $84,7 \%$ & 91 & $86,7 \%$ & 19 & $14,5 \%$ & 14 & $13,3 \%$ \\
\hline
\end{tabular}

For the purpose of calculating the average scores, the students who select Yes for the questions with positive content got 1 point score; got 1 point score for the negative expression (I am not interested in Stem Activities). Students who select different options receive 0 points. The higher the score means, the higher the level of knowledge and awareness about the Stem System.

Table 4. Students' knowledge and awareness level of STEM education

\begin{tabular}{ccccc}
\hline Measurement & Test & Mean & S.D. & p \\
\hline Stem System & Pre & 10,59 & 1,85 & \multirow{2}{*}{$0,01^{*}$} \\
Information and & Post & 12,33 & 1,43 & \\
Awareness level & & & \\
\hline
\end{tabular}

* Significant difference, paired t test was applied.

The data presented that the levels of Knowledge and Awareness about Stem System before and after education were different. It can be said that the reason for the difference is higher than the pre-education level and the level of knowledge and knowledge is effective $(\mathrm{p}=0.01, \mathrm{p}<0.05)$. 


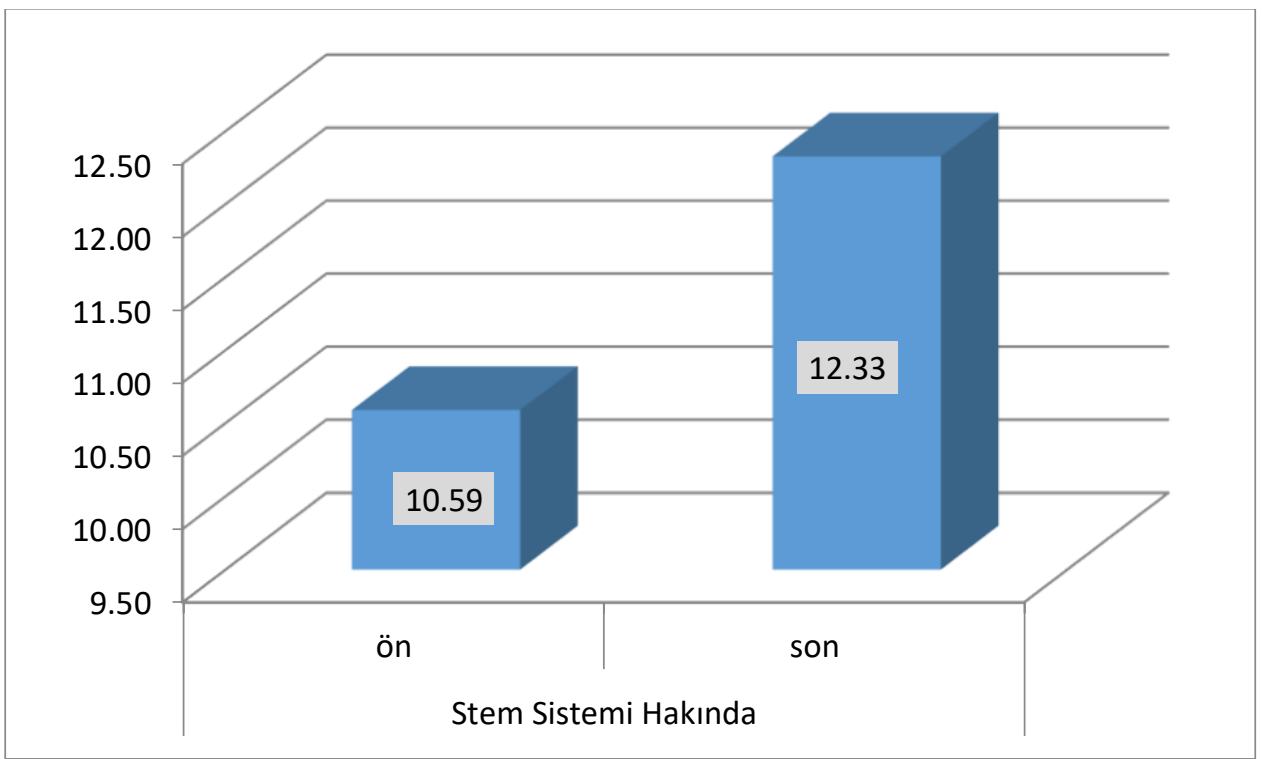

Figure 1. Students knowledge and awareness of STEM learning

Table 5. Students knowledge and awareness of STEM learning in relation to Gender

\begin{tabular}{ccccc}
\hline Gender & Steam Test & Mean & S.D. & p \\
\hline \multirow{2}{*}{ Male $(\mathbf{n}=\mathbf{1 3 1})$} & Pre & 10,52 & 1,80 & \multirow{2}{*}{$0,01^{*}$} \\
\hline \multirow{2}{*}{ Female $(\mathbf{n = 1 0 5})$} & Post & 12,34 & 1,43 & \multirow{2}{*}{$0,01^{*}$} \\
& Pre & 10,68 & 1,92 & 1,42 \\
\hline
\end{tabular}

* Significant difference, paired t test was applied.

The data shows that male students have different levels of knowledge and awareness about Stem System before and after education. It can be said that the reason for the difference is higher than the pre-education level and the level of knowledge and knowledge is effective $(\mathrm{p}=0.01, \mathrm{p}<0.05)$. It was determined that female students had different levels of knowledge and awareness about Stem System before and after education. It can be said that the reason for the difference is higher than the pre-education level and the level of knowledge and knowledge is effective $(\mathrm{p}=0.01, \mathrm{p}<0.05)$.

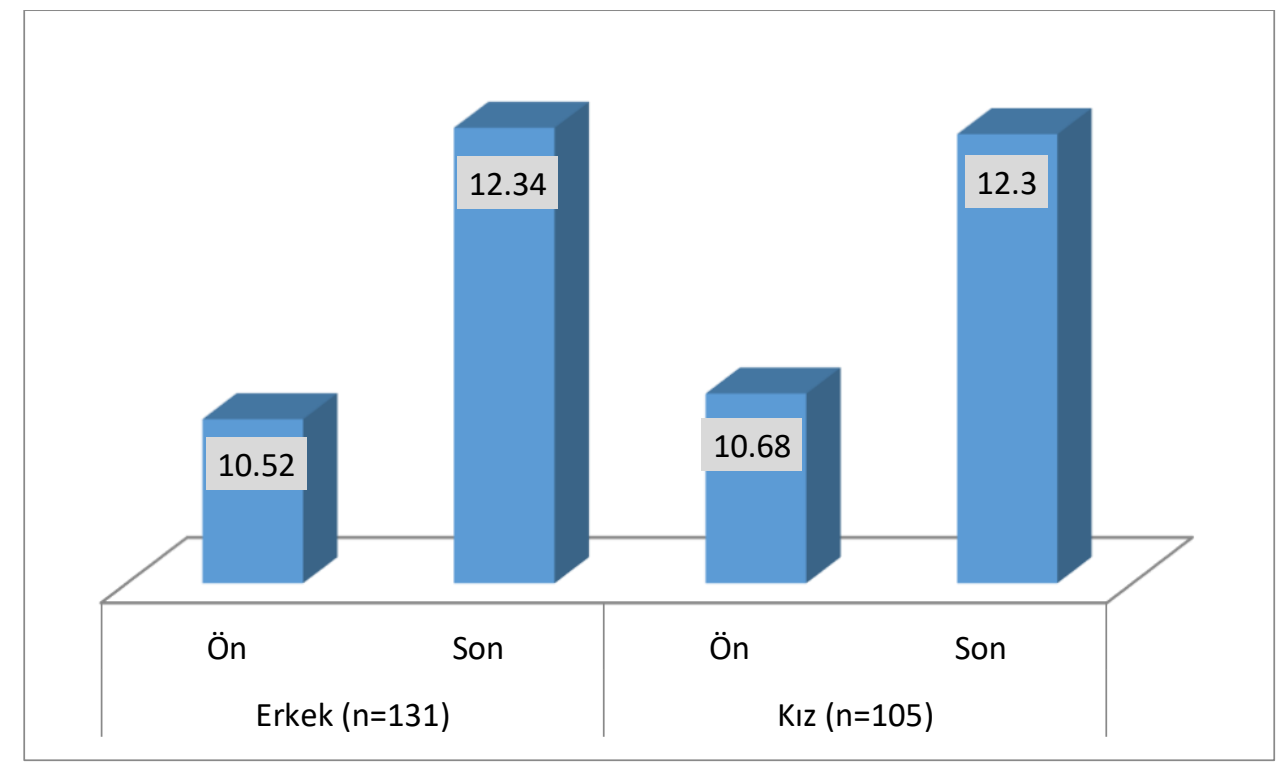

Figure 2. Knowledge and Awareness Level of Stem System in terms of Gender 
Table 6. Students knowledge and awareness of STEM learning in relation to age

\begin{tabular}{ccccc}
\hline Variables & & Pre & Post & Age \\
\hline \multirow{2}{*}{ Pre Test } & $\mathrm{r}$ & 1 & & \\
& $\mathrm{p}$ & & 1 & \\
\multirow{2}{*}{ Post Test } & $\mathrm{r}$ & 0,06 & & \\
\hline \multirow{2}{*}{ Age } & $\mathrm{p}$ & 0,34 & $0,16^{*}$ & 1 \\
& $\mathrm{r}$ & 0,01 & 0,01 & \\
\hline
\end{tabular}

It was determined that there was no significant relationship between pre-test scores and post-test scores. It was determined that the pre and post test scores of the students changed without being dependent on the pre-test scores $(r=0.06, p>0.05)$.

There was a positive correlation between pre-test scores and age. Pre-test scores of high-age students were also found to be high $(\mathrm{r}=0.47, \mathrm{p}<0.05)$.

It was determined that there was a positive, significant correlation between the post-test scores of the students and their age, at a very weak level. Post-test scores of high-age students were also found to be high $(r=0.16, p<0.05)$.

Table 7. Knowledge about the Stem System by Gender and Relationship between Awareness Level and Age

\begin{tabular}{|c|c|c|c|c|c|}
\hline & Gender & & Pre & Post & Age \\
\hline \multirow{3}{*}{ Male } & Pre & $\begin{array}{l}\mathrm{r} \\
\mathrm{p}\end{array}$ & 1 & & \\
\hline & Post & $\begin{array}{l}\mathrm{r} \\
\mathrm{p}\end{array}$ & $\begin{array}{l}0,04 \\
0,64\end{array}$ & 1 & \\
\hline & Age & $\begin{array}{l}\mathrm{r} \\
\mathrm{p}\end{array}$ & $\begin{array}{c}0,45^{* *} \\
0,01\end{array}$ & $\begin{array}{c}0,17^{*} \\
0,04 \\
\end{array}$ & 1 \\
\hline \multirow{3}{*}{ Female } & Pre & r & 1 & & \\
\hline & Post & $\begin{array}{l}\mathrm{r} \\
\mathrm{p}\end{array}$ & $\begin{array}{l}0,09 \\
0,37\end{array}$ & 1 & \\
\hline & Age & $\begin{array}{l}\mathrm{r} \\
\mathrm{p}\end{array}$ & $\begin{array}{c}0,49^{* *} \\
0,01\end{array}$ & $\begin{array}{c}0,16^{*} \\
0,04\end{array}$ & 1 \\
\hline
\end{tabular}

* Correlation analysis showed significant difference.

There was no significant correlation between pre-test scores and post-test scores of male students. Male students' pre and post test scores were found to change without being dependent on the pre-test scores $(r=0.04, p>0.05)$. It was determined that there was a positive, significant relationship between pre-test scores and age of the male students at a moderate level. Pre-test scores of male students with high ages were also found to be high $(r=0.47$, $\mathrm{p}<0.05$ ).

It was found that there was a positive, significant correlation between the post-test scores of the male students and the age of the students at a very weak level. Post-test scores of male students with high age were also found to be high $(r=0.17, p<0.05)$. There was no significant relationship between pre-test scores and post-test scores of female students. It was determined that the female students' pre-and post-test scores changed without being subject to change pre-test scores $(r=0.09, \mathrm{p}>0.05)$.

Data presented that there was a positive, significant relationship between pre-test scores and age of the girls and a moderate level. Pre-test scores of female students with high age were found to be high $(r=0.49, p<0.05)$. It was determined that there was a positive, significant correlation between the post-test scores of the female students and their ages at a very weak level. The final test scores of the high school girls were also high $(r=0.16, p<0.05)$. 


\section{Conclusion}

In this report we investigated the impact of after school STEM clubs on children's attitudes to STEM related subjects. 236 children aged 8-12 took part in this study. Data analysis shows that children have developed positive attitudes towards STEM areas after long and planned STEM trainings which was applied to 236 students aged 812. The data also presented that participating in long-term STEM clubs had positive effect on children's learning. In order to meet the need for workforce in STEM areas in the world in the future, it is crucial to plan and implement long term STEM clubs. This would also be useful for raising the interest of young students in STEM occupations.

In longitudinal and planned Stem training, there was no significant difference in the increase in the interest in the Stem areas in the 8-12 age groups, but it can be said that the ratio is slightly higher in boys. From this point of view, it is possible to state that girls are directed to the STEM areas when they are offered equal opportunities. Participation of girls in the labour force in Stem areas will contribute greatly to the economies of that country.

\section{References}

Allsop, Y. (2017). Computer Science: Silent C in STEM. In S. Humble (Ed.), Creating the Coding Generation in Primary Schools: A Practical Guide for Cross-Curricular Teaching (Hardback). Routledge.

Bybee, R. W. (2010). Advancing STEM education: A 2020 vision. Technology and Engineering Teacher, 70(1), 30.

Caprile, M. et al. (2015), Encouraging STEM studies for the Labour Market, Study for the EMPL Committee, The European Union.

Huber, M.T., Hutchings, P, and Gale, R. (Summer/Fall 2005). Integrative learning for liberal education. Peer Review. Association of American Colleges and Schools: Washington, DC.

[Online], Available: http://www.aacu.org/peerreview/pr-sufa05/pr_sufa05 analysis.pdf [February 2019]

Intel Corporation (2015) Increasing employability and accelerating economic growth worldwide. [Online], Available: http://www.intel.com/content/dam/www/public/us/en/documents/brief/innovatio n-for-employabilitybrief.pdf [February 2019]

Kelley, T. R., \& Knowles, J. G. (2016). A conceptual framework for integrated STEM education. International Journal of STEM Education, 3(1), 11.

Moore, T. J., Stohlmann, M. S., Wang, H. H., Tank, K. M., Glancy, A. W., \& Roehrig, G. H. (2014). Implementation and integration of engineering in K-12 STEM education. In Engineering in pre-college settings: Synthesizing research, policy, and practices. Purdue University Press.

National Research Council. (2011). Successful K-12 STEM education: Identifying effective approaches in science, technology, engineering, and mathematics. National Academies Press.

Roehrig, G. H., Johnson, C. C., Moore, T. J., \& Bryan, L. A. (2015). Integrated STEM education. In STEM Road Map (pp. 35-50). Routledge.

Watson, A. D., \& Watson, G. H. (2013). Transitioning STEM to STEAM: Reformation of engineering education. Journal for Quality and Participation, 36(3), 1-5 